\title{
The Effect of Leadership Style on Employee Retention at Ayodya Resort Bali with Non-Physical Work Environment as Moderating Variable
}

\author{
I. G. B. Krisna Dwipayana and I. Gusti Made Suwandana
}

\section{ABSTRACT}

\begin{abstract}
This study aims to analyze the effect of leadership style, work environment on employee retention with non-physical work environment as a moderating variable. The research design used is associative. The research was conducted at Ayodya Resort Bali. The population of this study was 501 employees with 84 employees as samples. The sample selection technique is proportional stratified. The data collection method used is Observation, Interview, Questionnaire and analyzed by Moderated Regression Analysis (MRA). The results show that leadership style has a positive and significant effect on employee retention, the better the leadership style applied by the company, the employee's desire to remain in the company will also increase. The non-physical work environment strengthens the influence of leadership style on employee retention, the better the leadership style supported by a good non-physical work environment, the employee's desire to remain in the company will increase. Companies must always pay attention to the relationship between employees and the relationship between employees and superiors so that they continue to run well and harmoniously.
\end{abstract}

Keywords: Employee Retention, leadership style, Non-physical work environment.

\author{
Submitted : September 07, 2021 \\ Published : December 29, 2021 \\ ISSN: $2507-1076$ \\ DOI: $10.24018 / \mathrm{ejbmr} .2021 .6 .6 .1093$ \\ I. G. B. Krisna Dwipayana \\ Faculty of Economy and Business, \\ Udayana University, Bali, Indonesia. \\ (e-mail: dwipayanak00@gmail.com) \\ I. Gusti Made Suwandana \\ Faculty of Economy and Business, \\ Udayana University, Bali, Indonesia.
}

*Corresponding Author

\section{INTRODUCTION}

According to the TripAdvisor Traveler's Choice Award (2021), Bali is the number one tourist destination in the world. The progress of tourism in Bali will certainly never be separated from accommodation, because this accommodation service is one of the attractions for tourists to enjoy their vacation. Competition between accommodations is common, and employee professionalism is the main thing in winning the competition.

Companies that win the competition are companies that have skilled, professional, and loyal employees. However, not all accommodation companies can retain their employees (Fahim, 2019). Every employee in the organization certainly has different wants, needs and goals, for that they need to be nurtured so that their respective goals can be integrated with the company's goals (Yuniarti \& Suprianto, 2020). The causative factor can be due to individual factors but can also be due to the influence of the work environment and leadership style of the company. Due to the intense competition between accommodations, of course the quality of employees will continue to be improved by superiors, and often the leadership style and work environment will affect employee retention.

Employee retention is a process in which employees are encouraged to remain in the company until the end of the period (Adzka \& Perdhana, 2017). Employee retention has the aim of maintaining and or improving the physical, mental and attitude of employees (Nantsupawat, 2017), so that they remain loyal and work productively to support the achievement of the goals of a company (Aprilia \& Mukti, 2018). Employee retention is a policy and practice that organizations use to keep valuable employees out of their jobs (Disa \& Djastuti, 2019).

The company is obliged to retain the most valuable, resilient, efficient, and productive employees for the competition. employee retention is a set of activities and processes to maintain high-performing and high-potential employees so that they always contribute according to the standards expected by the organization. Therefore, retaining skilled employees is important for the company to maintain the service quality of the company (Purnamasari \& Netra, 2020). As happened in Ayodya Resort Bali, which has a high employee retention. Ayodya Resort Bali's employee retention rate from 2016 to 2021 has a downward trend, influenced by the Covid-19 pandemic situation. It is known that the lowest retention rate is in 2020, which is 75 percent.

Leadership plays an important role in company management (Saiyed, 2019). Leadership is needed by humans because of certain limitations in humans. This is where the need to be led and lead arises (Kia et al., 2019). Leadership is defined in terms of individual characteristics, habits, ways of influencing others, interactions, position in the organization and perceptions of legitimate influence (Aboramadan \& Dahleez, 2020). This situation illustrates that leadership is very necessary, if an organization or company has differences 
with others, it can be seen from the extent to which its leaders can work effectively (Pawirosumarto et al., 2017). Leadership style can maximize productivity, job satisfaction, and easily adapt to all situations (Saputra \& Danim, 2019).

The leadership style applied in Ayodya Resort Bali is a democratic leadership style when the role of all parties is needed and will apply an autocratic leadership style when important matters are the authority and policy of management and the company. Management support and leadership are one of the factors that affect employee retention (Kossivi et al., 2016). Leadership style had a significant positive effect on employee retention (Khalid et al., 2016). Leadership style has a significant effect on employee retention at Zenith bank, Nigeria and the Nigerian banking sector in general (Favour, 2016).

Employee retention rates are also influenced by the work environment (Kundu \& Lata, 2017). The work environment is everything outside the organization that has the potential to affect employees at work and ultimately affect organizational performance (Yusliza et al., 2021). The work environment is divided into a physical work environment and a non-physical work environment. The physical work environment is all physical conditions that exist around the workplace that can affect employees (Bibi et al., 2018). Meanwhile, the nonphysical work environment is all conditions that occur related to work relationships, both with superiors and coworkers, or subordinates (Lyons \& Bandura, 2020). Organizations that are able to provide a non-physical work environment that is in accordance with the level of privacy and voice control of employees, have a very good opportunity to retain employees in the organization (Agarwal, 2016).

Several studies have shown that the work environment is able to moderate or strengthen the influence of leadership style on employee retention. The work environment has a positive and significant effect on employee retention and the physical work environment partially has a positive effect on turnover intention. Turnover intention is closely related to employee retention because high turnover intention results in low employee retention (Worang \& Mujiati, 2020). In contrast, Ruby (2017) found that the work environment had a positive but not significant effect on employee retention (Ruby, 2017).

\section{LITERATURE REVIEW}

Management support and leadership are one of the factors that affect employee retention (Kossivi et al., 2016). Leadership style can maximize productivity, job satisfaction, and easily adapt to all situations (Saputra \& Danim, 2019). This situation illustrates that leadership is needed if an organization. or companies have differences with others can be seen from the extent to which the leaders can work effectively. There is a significant positive influence of leadership style on employee retention in research in Pakistani banking, this study has shown a very complete study, which proves that there is indeed a significant positive effect on leadership style on retention. Employee (Khalid et al., 2016). Leadership style has a significant effect on employee retention at Zenith bank, Nigeria and the Nigerian banking sector in general (Favour, 2016). There is a significant relationship between leadership and employee retention in Tanzanian commercial banks (Mwita \& Tefurukwa, 2018). Based on the empirical evidence from the studies used, the following hypothesis can be made which is the formulation of the hypothesis:

H1: Leadership style has a significant effect on employee retention.

Organizations that are able to provide a work environment that is in accordance with the level of privacy and voice control of employees, have a very good opportunity to retain employees in the organization (Agarwal, 2016). The work environment has a positive and significant effect on employee retention at primary school level non-permanent teachers in Adimulyo district, the results of the study used are the approach of the non-physical work environment relationship as a moderator of employee retention (Irianto, 2018). The non-physical work environment partially has a significant positive effect on turnover intention (Worang \& Mujiati, 2020). Turnover intention is very closely related to employee retention, high turnover intention results in low employee retention, this study is used as an approach to employee retention in terms of turnover intention and can be used as a support for the moderating hypothesis. The influence of the work environment on turnover intention is significantly positive, this research is used to support the non-physical work environment as a moderator of retention, as turnover is closely related to employee retention and can be used simultaneously (Marezza, 2016). Based on the empirical evidence from the studies used, the following hypothesis can be made which is the formulation of the hypothesis:

$\mathrm{H} 2$ : Work environment moderates the effect of leadership style on employee retention.

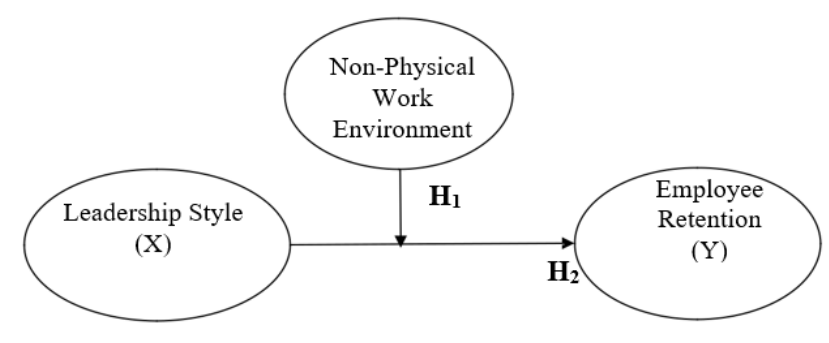

Fig. 1. Conceptual Framework.

\section{Methodology}

The research design used in this study is associative. The research location was conducted at Ayodya Resort Bali. The object of this research is leadership style, non-physical work environment, and employee retention, permanent employees at Ayodya Resort Bali.

The population in this study is 501 permanent employees who work at Ayodya Resort Bali starting in 2021 in April. The sample used in this study were 84 permanent employees of Ayodya Resort Bali. The number of samples obtained from the Slovin formula. The sample selection technique is proportional stratified. The data collection methods used in this study were observation, interviews, and questionnaires. The data measurement scale used in this study is the Likert scale. The analytical test used in this research is Moderated Regression Analysis (MRA). 


\section{RESULtS}

MRA is a special application of multiple linear regression, where the regression equation contains elements of interaction (multiplication of two or more independent variables). The regression coefficient analysis test will use the Moderated Regression Analysis (MRA) test. The results of the moderated regression analysis in this study are as follows.

\begin{tabular}{|c|c|c|c|c|c|c|}
\hline & \multirow[t]{2}{*}{ Model } & \multicolumn{2}{|c|}{$\begin{array}{c}\text { Unstandardized } \\
\text { Coefficients }\end{array}$} & \multirow{2}{*}{$\begin{array}{c}\text { Standardized } \\
\text { Coefficients }\end{array}$} & \multirow[t]{2}{*}{$\mathrm{t}$} & \multirow[t]{2}{*}{ Sig. } \\
\hline & & $\mathrm{B}$ & Std. Error & & & \\
\hline \multirow{5}{*}{1} & (Constant) & -10.275 & 4.745 & & -2.166 & 0.033 \\
\hline & Leadership Style & 0.574 & 0.215 & 0.796 & 2.666 & 0.009 \\
\hline & $\begin{array}{c}\text { Work } \\
\text { environment }\end{array}$ & 0.879 & 0.297 & 0.835 & 2.958 & 0.004 \\
\hline & X.M & 0.116 & 0.012 & 0.676 & 2.304 & 0.016 \\
\hline & $\begin{array}{l}\text { R Square: } .717 \\
\text { F. sig: } .000\end{array}$ & & & & & \\
\hline
\end{tabular}

The value of the coefficient of determination or R Square is 0.717 . This value can be interpreted that 71.7 percent of leadership style affects employee retention where the nonphysical work environment is a moderator, while 28.3 percent is influenced by other variables. test results sig. F of 0.000 which is smaller than alpha $0.05(0.000<0.05)$. This shows that the leadership style and work environment have a simultaneous or joint effect on employee retention.

\section{A. Leadership Style on Employee Retention}

The value of the influence of leadership style $(\mathrm{X})$ on employee retention ( $\mathrm{Y}$ ) is 0.574 with a sig.t value comparison of 0.009 less than the significant value used $(0.001<0.05)$. This figure shows that leadership style has a positive and significant effect on employee retention. This means that the better the leadership style applied by the company, the employee's desire to remain in the company will also increase. Conversely, the worse the leadership style applied by the company, the employee's desire to remain in the company will decrease. Previous research has proven that leadership style has an effect on employee retention. Management support and leadership are one of the factors that affect employee retention (Kossivi et al., 2016). Leadership style can maximize productivity, job satisfaction, and easily adapt to all situations (Saputra \& Danim, 2019). These results also support previous research (Khalid et al., 2016; Favour, 2016; Mwita \& Tefurukwa, 2018) which states that the leadership style variable has a positive and significant effect on employee retention.

\section{B. Non-physical Work Environment Moderates Leadership Style on Employee Retention}

Based on the results of the analysis, it can be seen that the significant value for the leadership style variable with a nonphysical work environment as moderating is 0.016 less than $0.05(0.01 \mathrm{z}<0.05)$ so that the hypothesis is accepted, in other words, the non-physical work environment strengthens the influence of leadership style on employee retention. This means that the better the leadership style supported by a good non-physical work environment, the employee's desire to remain in the company will also increase, on the contrary the worse the leadership style that is applied and not supported by a good non-physical work environment then the desire of employees to remain in the company will also decrease.
Previous research has proven that the non-physical work environment strengthens the influence of leadership style on employee retention. Organizations that are able to provide a work environment that is in accordance with the level of privacy and voice control of employees, have a very good opportunity to retain employees in the organization (Agarwal, 2016). These results also support previous research which state that the work environment is able to moderate the influence of leadership style on employee retention (Worang \& Mujiati, 2020; Irianto, 2018; Marezza, 2016).

\section{Implication}

This study has been able to explain the theoretical model used as the basis for formulating the hypothesis, namely the influence of leadership style on employee retention with a non-physical work environment as a moderating variable. The results of the theoretical model explain that the factors that influence consumer employee retention are the application of leadership styles and are reinforced by a good non-physical work environment. This research raises practical implications for Ayodya Resort Bali and other companies so that they can use this research as input for learning references.

\section{Research Limitations}

This research has been proposed and carried out according to scientific procedures. However, there are still limitations in this study where the number of respondents is only 84 people and only discusses the behavior of Ayodya Resort Bali employees so that the results of this study cannot be generalized to other companies. There are many other variables that can affect employee retention outside the model described in this study.

\section{CONCLUSION}

Leadership style has a positive and significant effect on employee retention. This means that the better the leadership style applied by the company, the employee's desire to remain in the company will also increase. The non-physical work environment strengthens the influence of leadership style on employee retention. This means that the better the leadership style supported by a good non-physical work environment, the employee's desire to remain in the company will also increase.

Based on the results of the research, leadership style has a significant positive effect on employee retention, therefore, to improve and maintain employee retention, Ayodya Resort Bali superiors should pay attention to the leadership style that will be applied when dealing with employees, including distinguishing situations where and when to use leadership style. democratic and when to use an autocratic leadership style. In addition, employees will feel happy if their leaders provide opportunities for opinion in decision making, are able to motivate employees, communicate well with employees, have a sense of responsibility towards employees, and are able to control their emotions when carrying out tasks.

Employee retention can also be strengthened by a good non-physical work environment. Therefore, Ayodya Resort Bali should always pay attention to the relationship between employees and the relationship between employees and 
superiors so that it continues to run well and harmoniously.

\section{FUTURE RESEARCH}

For the next researcher, it is necessary to consider examining other variables, factors, and indicators outside of leadership style and non-physical work environment to determine the effect of employee retention. Such as internal communication variables, work stress, incentives, and others.

\section{REFERENCES}

Aboramadan, M., \& Dahleez, K. . (2020). Leadership styles and employees' work outcomes in nonprofit organizations: the role of work engagement. Journal of Management Development, 39(7), 869-893. https://doi.org/https://doi.org/10.1108/JMD-12-2019-0499.

Adzka, S. A. A., \& Perdhana, M. S. (2017). Analisis Faktor yang Mempengaruhi Retensi Karyawan. Diponegoro Journal of Management, 6(4), 922-928.

Agarwal, U. . (2016). Examining Perceived Organizational Politics Among Indian Managers: Engagement as Mediator and Locus of Control as Mediator. International Journal of Organizational Analysis, 24(3), 415-437.

Aprilia, F., \& Mukti, A. H. (2018). Pengaruh Lingkungan Kerja Dan Perceived Organization Support (Pos) Terhadap Kepuasan Kerja Dan Dampaknya Terhadap Retensi Karyawan. Jurnal Ilmiah Bisnis, Pasar Modal, Dan UMKM, 1(1), 19-26.

Bibi, P., Ahmad, A., \& Majid, A. H. . (2018). HRM Practices and Employee Retention: The Moderating Effect of Work Environment. Tourism and Hospitality Research, 1(1), 129-152. https://doi.org/https://doi.org/10.1108/978-1-78756-699-620181007.

Disa, L. Z., \& Djastuti, I. (2019). Analisis pengaruh penghargaan dan pengembangan karier terhadap retensi karyawan dengan kepuasan kerja sebagai variabel intervening (Studi pada Karyawan Perum LPPNPI AirNav Indonesia Kota Tangerang). Diponegoro Journal of Management, 1(1), 81-95.

Fahim, M. G. . (2019). Strategic human resource management and public employee retention. Review of Economics and Political Science, 3(2), 20-39. https://doi.org/https://doi.org/10.1108/REPS-07-2018-002.

Favour, A. A. (2016). An Investigation into the Impact of Leadership Styles on Employee Retention: Identifying which Leadership Style best encourages Employee Retention in the Nigerian Banking Sector. National College of Ireland, 1(1), 1.

Irianto, D. (2018). Effect of Non-Physical Work Environment and Perceived Organizational Support on Retention with Job Satisfaction as Intervening Variable. Journal of STIE Putra Bangsa., 1(1), 1.

Khalid, N., Pahi, M. H., \& Ahmed, U. (2016). Losing your best talent: Can leadership retain employees? The dilemma of the banking sector of Hyderabad Sindh, Pakistan: A mediation investigation. International Review of Management and Marketing, 6(3), 608-616.

Kia, N., Halvorsen, B., \& Bartram, T. (2019). Ethical leadership and employee in-role performance: The mediating roles of organisational identification, customer orientation, service climate, and ethical climate. Personnel Review, 48(7), 1716-1733. https://doi.org/https://doi.org/10.1108/PR-12-2018-0514.

Kossivi, B., Xu, M., \& Kalgora, B. (2016). Study on determining factors of employee retention. Open Journal of Social Sciences, 4(5), 261.

Kundu, S. C., \& Lata, K. (2017). Effects of supportive work environment on employee retention: Mediating role of organizational engagement. International Journal of Organizational Analysis, 25(4), 703-722. https://doi.org/https://doi.org/10.1108/IJOA-12-2016-1100.

Lyons, P., \& Bandura, R. (2020). Employee turnover: features and perspectives. Development and Learning in Organizations, 34(1), 1-4. https://doi.org/https://doi.org/10.1108/DLO-02-2019-0048.

Marezza, A. (2016). Pengaruh Lingkungan Kerja Non Fisik Dengan Kepuasan Kerja Sebagai Variabel Intervening Terhadap Turnover Intention Karyawan PT. Andika Lintas Samudera Banjarmasin. Jurnal Bisnis Dan Pembangunan, 5(2), 1.

Mwita, K. M., \& Tefurukwa, O. (2018). The influence of leadership on employee retention in Tanzania commercial banks. Leadership, $8(2), 1$.

Nantsupawat, A. (2017). Effects of nurse work environment on job dissatisfaction, burnout, intention to leave. International Nursing Review, 64(1), 91-98.

Pawirosumarto, S., Sarjana, P. K., \& Gunawan, R. (2017). The effect of work environment, leadership style, and organizational culture towards job satisfaction and its implication towards employee performance in
Parador Hotels and Resorts, Indonesia. International Journal of Law and Management, 59(6), 1337-1358. https://doi.org/https://doi.org/10.1108/IJLMA-10-2016-0085.

Purnamasari, N. P. L., \& Netra, I. G. S. K. (2020). The Effect of Compensation and Internal Communication on Employee Engagement and Turnover Intention in Sankara Ubud Resort and Spa, Gianyar, Bali. American Journal of Humanities and Social Sciences Research, 4(1), $353-359$.

Ruby, T. (2017). Pengaruh kompensasi dan lingkungan kerja terhadap retensi karyawan pabrik PT. Pradha Karya Perkasa. Doctoral dissertation, Widya Mandala Catholic University Surabaya.

Saiyed, A. A. . (2019). The role of leadership in business model innovation: a case of an entrepreneurial firm from India. New England Journal of $\begin{array}{lll}\text { Entrepreneurship, } & 22(2), & 70-88 .\end{array}$ https://doi.org/https://doi.org/10.1108/NEJE-08-2019-0040.

Saputra, E., \& Danim, S. (2019). Pengaruh gaya kepemimpinan kepala sekolah dan suasana kerja terhadap kinerja guru. Manajer Pendidikan, 13(3), 249-259.

Worang, B. A. J., \& Mujiati, N. W. (2020). Effect of work stress and employee compensation on turnover intention with physical work environment as moderation. E-Journal of Management, 9(5), 17581777.

Yuniarti, D., \& Suprianto, E. (2020). Pengaruh gaya kepemimpinan dan tingkat Pendidikan terhadap kinerja karyawan pada direktoreat operasi/produksi PT. X. Jurnal Industri Elektro Dan Penerbangan, $4(2), 1$.

Yusliza, M. ., Noor Faezah, J., Ali, N., Mohamad Noor, N. ., Ramayah, T., Tanveer, M. I., \& Fawehinmi, O. (2021). Effects of supportive work environment on employee retention: the mediating role of personorganisation fit. Industrial and Commercial Training, 53(3), 201-216. https://doi.org/https://doi.org/10.1108/ICT-12-2019-0111. 